\title{
The behavioural-driven response of the Drosophila imago transcriptome to different types of modified gravity
}

\author{
Raul Herranz ${ }^{1,2^{*}}$, Richard J.A. Hill ${ }^{3}$, Camelia E. Dijkstra ${ }^{4,5}$, Laurence Eaves ${ }^{3}$, Jack J.W.A. van Loon ${ }^{2,6}$ and F. Javier Medina ${ }^{1}$ \\ *Correspondence: r.herranz@csic.es \\ ${ }^{1}$ Centro de Investigaciones Biológicas (CSIC), Ramiro de Maeztu 9, E-28040, Madrid, Spain. \\ ${ }^{2}$ European Space Research \& Technology Center - European Space Agency (ESTEC-ESA) Keplerlaan,12201 AZ Noordwijk, The \\ Netherlands. \\ ${ }^{3}$ School of Physics \& Astronomy, University of Nottingham, Nottingham NG7 2RD, UK. \\ ${ }^{4}$ Coventry University, Faculty of Health and Life Sciences, Coventry, CV1 5FB, UK. \\ ${ }^{5}$ School of Biosciences, University of Nottingham, Sutton Bonington Campus, Loughborough, LE12 5RD UK. \\ ${ }^{6}$ DESC (Dutch Experiment Support Center), Department of Oral and Maxillofacial Surgery/Oral Pathology, VU University Medical \\ Center \& Department of Oral Cell Biology Academic Centre for Dentistry Amsterdam (ACTA), Amsterdam, The Netherlands \& \\ MMG0-Lab, ESTEC, European Space Agency (ESA), Noordwijk, The Netherlands.
}

\begin{abstract}
Genome-wide transcriptional profiling experiments on the International Space Station (ISS) have revealed important alterations in the gene expression of Drosophila. In contrast, simulated microgravity experiments in Earth-based laboratories, where the particular constraints and conditions in orbiting spacecraft are absent, show weaker changes in gene expression. Here we use the "gene expression dynamics inspector" (GEDI) self-organizing maps to investigate the effect of altered gravity on different populations of Drosophila. We employ diamagnetic levitation and different mechanical techniques to generate microgravity and hypergravity and compare the changes in gene expression in these modified environments. In addition to behavioural and reproductive responses detected at the gene expression level, our results also indicate a subtle response of the transcriptome that is finely-tuned to Earth's gravity.
\end{abstract}

Keywords: Microgravity, microarray, hypergravity, gene expression, magnetic levitation, RPM, LDC, ground based facilities

\section{Introduction}

Understanding the way in which biological organisms detect and adapt their molecular systems, particularly their transcriptome, to microgravity is important for optimising life-support systems and safety in future space missions. Although previous investigations [1-5] have not yet led to a consensus on how the environment in spacecraft affects the genetic behaviour of living organisms, studies of the overall transcriptome response to microgravity of some species [6], including Drosophila [7], have revealed interesting effects.

Two distinct experimental approaches can be used to evaluate the effect of altered gravity on living organisms, namely experiments in orbiting spacecraft, where the force of gravity is reduced by at least three orders of magnitude, or techniques that simulate modified gravity using ground-based facilities (GBF). The latter include mechanical systems such as clinostats, random positioning machines (RPM), drop towers, plus large radius centrifuges such as the Large Diameter Centrifuge (LDC) located at the ESA Research Centre in The Netherlands (ESTEC) [8-13] that allows minization of shear forces. An alternative ground-based approach is magnetic levitation, in which the diamagnetic force generated by a powerful magnet balances the force of gravity [14-20]. Magnetic levitation exploits the property of diamagnetism in materials such as water, starch, oils, and fats, which are normally thought to be non-magnetic. When these materials are placed in a strong magnetic field, the motion of the bound electrons in the constituent atoms and/or molecules is slightly modified, generating a magnetic dipole moment vector which is oriented opposite to the applied magnetic field. By using a solenoid in which the magnetic field and its gradient are sufficiently large, the interaction between this induced dipole and the magnetic field gives rise to a diamagnetic force which is strong enough to balance the force of gravity on the atoms and molecules, so that the object under investigation can levitate freely. When diamagnetic levitation is used to investigate the effect of modified gravity on biological matter or living objects, it is necessary to undertake carefully control experiments to distinguish between effects arising from the levitation effect alone and those arising from the presence of the strong magnetic field. For example, the forces on biologically important paramagnetic molecules and ions such as $\mathrm{O}_{2}$ and $\mathrm{Fe}^{2+}$ in strong magnetic field can influence fluid flow: recent work studying the effects of magnetic levitation on a liquid bacterial culture concluded that magnetically-driven convection, arising due to a concentration gradient of dissolved $\mathrm{O}_{2}$ in the culture, influenced growth rates [17]. We label the points in the magnetic field where the effective gravity acting on water is precisely zero, $1 g$ and $2 g$ as $0 g^{*}, 1 g^{*}$ and $2 g^{*}$ points, 
Herranz et al. Genomics Discovery 2013,

respectively. The asterisk is used as a reminder that the labels refer to the effective gravity on water, and also to indicate that there is a strong magnetic field present (approximately $12 \mathrm{~T}$ at the $0 g^{*}$ and $2 g^{*}$ points, and $16 \mathrm{~T}$ at the $1 g^{*}$ point). The point at which flies levitate was determined in [18] to be close to the stable levitation point of water (i.e. close to $\mathrm{a} 0 \mathrm{~g}^{*}$ point).

In this article, we use whole-genome microarray platforms to investigate how different types of altered gravity conditions generated by ground-based facilities affect the gene expression profile of young Drosophila melanogaster female populations exposed to these conditions for 3-4 days. In addition, we include a second set of experiments performed on other populations to confirm the generality of the results. We find that the exposure of Drosophila to altered gravity produces a subtle response of the transcriptome which is sensitive to the environmental conditions and to the particular type of ground-based facility used. In addition, some effects on the expression of behaviour-related genes are common to all of our measurements in GBFs.

\section{Materials and methods Ground based facilities}

Two mechanical GBFs were used to simulate altered gravity at the DESC/ESTEC Laboratory, Noordwijk, The Netherlands; microgravity was simulated using a mechanical random positioning machine (RPM, real random mode at maximum angular speed of $60 \mathrm{rpm}$ ) and hypergravity conditions were simulated with the large diameter centrifuge $\left(2 g^{*}\right.$, where \# denotes mechanically-induced simulated gravity). We used an external $1 g^{\#}$ control in all three GBF experiments. At the University of Nottingham, a specially-designed high magnetic field superconducting solenoid system was used to simulate both microgravity by diamagnetic levitation $\left(0 g^{*}\right.$, where * denotes that a high magnetic field is applied during the simulations) in the upper part of the magnet bore and simulated hypergravity $\left(2 g^{*}\right)$ in the lower part of the bore where the magnetic force vector is directed downwards, thus adding to the force of gravity. In these positions, the flies also experienced a field $B=12.5 \mathrm{~T}$. Additionally, we investigated simultaneously the effect of a strong magnetic field (16 T) in the presence of normal gravity $\left(1 \mathrm{~g}^{*}\right)$ at the centre of the magnet bore. However, an optimal complementary control in the $1 g^{*}$ position would have been with a field of 12.5 $\mathrm{T}$, corresponding to that in the $0 g^{*}$ and $2 g^{*}$ positions. This additional control cannot be done simultaneously in the magnet and it was not carried out because it would have required an additional lengthy round of experiments which time and budget constraints did not allow.

\section{Biological materials}

We performed the same experiment in the three GBF (young female Drosophila melanogaster Oregon $\mathrm{R}$ exposed to altered gravity for 3-4 days), but secondary experiments with different populations (males or mature imagoes) were also carried out in each simulator. To analyze the transcriptional profile of Drosophila, at least two biological replicas including 8 (females) to 12 (males) imagoes from each condition that passed the normal quality tests of the extracted RNA were used in a microarray analysis. A summary of the conditions and samples is given in Table 1. All samples were processed using Affymetrix Drosophila (Drosophila Genome2) chips covering near the whole fly coding genome. A validation of this approach, including qRT-PCR has been already published by our team [7].

\section{Gene expression data analysis}

A clustering, GEDI analysis was made using version 2.1 of this free software. First, we applied the RMA algorithm for background correction, normalization and expression level summarization of the arrays (see above) using GeneSpring software (Agilent Technologies) giving 18952 probe sets common probe sets to all conditions. Next, we calculated the average signal ratios for each experimental condition versus the proper control ( $1 \mathrm{~g}$ except in the magnet II experiment in which $1 \mathrm{~g} / 24^{\circ} \mathrm{C}$ condition was toke), and used this value for GEDI analysis. Mosaics of $20 \times 16$ grid size (average of 59 genes/tile) were obtained using the following settings of the software:

Training iterations: first phase: 60 second phase: 120 Neighborhood radius: first phase: 4.0 second phase: 1.0 Learning factor: first phase: 0.5 second phase: 0.05 Neighborhood block size: first phase: 4 second phase: 2 Conscience: first phase: 3.0 second phase: 3.0

Random seed:1 Distance metrics:Euclidean Linear Initialization Method

Gene lists affected by the treatments were extracted by hand from the GEDI images. Gene Ontology enrichment analysis of them was performed using Gene Spring Software using a raw $p$-value $<0.001$.

\section{Results}

Simulated microgravity/hypergravity produce subtle effects in the overall gene expression pattern in Drosophila imagoes

Populations of Drosophila with different gender and age were exposed to modified gravity using mechanical techniques or diamagnetic levitation. The experimental designs are summarized in Table 1, which also includes the microarray identification names for the hybridized Affymetrix Drosophila2 genome arrays used in the experiments. To obtain an overview of the transcriptome response to the different environments, we analyzed the microarray data with the "Gene Expression Dynamics Inspector" (GEDI) program [21]. GEDI is a "Self Organizing Map" based software that permits the visualization of gene expression patterns in mosaics of $n \times m$ tiles. Each tile corresponds to a cluster of genes that behaves similarly 
Herranz et al. Genomics Discovery 2013,

http://www.hoajonline.com/journals/pdf/2052-7993-1-1.pdf

Table 1. Description of the 50 CEL files used (Accession number GEO NCBI GSE33801).

\begin{tabular}{|c|c|c|c|c|c|c|c|}
\hline $\begin{array}{c}\text { Device \& } \\
\text { environment }\end{array}$ & $\begin{array}{c}\text { Final age } \\
\text { (from hatching) }\end{array}$ & Gender & \multicolumn{2}{|c|}{ Condition } & \multicolumn{3}{|c|}{ Name of CEL file replicates } \\
\hline \multirow{4}{*}{ 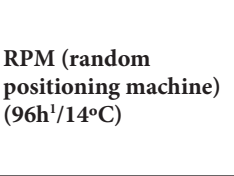 } & \multirow{4}{*}{5 days } & \multirow{2}{*}{ Females } & $\operatorname{Sim} \mu \mathrm{g}^{\#}$ & $90 \mathrm{~A}$ & $90 \mathrm{~B}$ & $90 \mathrm{C}$ & --- \\
\hline & & & $1 g$ & $91 \mathrm{~A}$ & $91 \mathrm{~B}$ & $91 \mathrm{C}$ & --- \\
\hline & & \multirow{2}{*}{ Males } & $\operatorname{Sim} \mu \mathrm{g}^{*}$ & $90 \mathrm{E}$ & $90 \mathrm{~F}$ & $90 \mathrm{G}$ & $90 \mathrm{H}$ \\
\hline & & & $1 g$ & $91 \mathrm{E}$ & $91 \mathrm{G}$ & $91 \mathrm{H}$ & --- \\
\hline \multirow{5}{*}{$\begin{array}{l}\text { Magnetic levitator I } \\
\left(72 \mathrm{~h} / 14^{\circ} \mathrm{C}\right)\end{array}$} & \multirow{5}{*}{5 days } & \multirow{5}{*}{ Females } & $0 g^{*}$ & $30 \mathrm{D}$ & $30 \mathrm{E}$ & $30 \mathrm{~F}$ & --- \\
\hline & & & $1 g^{*}$ & $31 \mathrm{D}$ & $31 \mathrm{E}$ & $31 \mathrm{~F}$ & --- \\
\hline & & & $2 g^{*}$ & $32 \mathrm{D}$ & $32 \mathrm{E}$ & $32 \mathrm{~F}$ & --- \\
\hline & & & $\lg \left(14^{\circ} \mathrm{C}\right)$ & $3 \mathrm{cD}$ & --- & $3 \mathrm{cF}$ & --- \\
\hline & & & $1 g\left(24^{\circ} \mathrm{C}\right)$ & $3 o D$ & $3 \mathrm{oE}$ & $3 o F$ & --- \\
\hline \multirow{5}{*}{$\begin{array}{l}\text { Magnetic levitator II } \\
\left(80 \mathrm{~h} / 14^{\circ} \mathrm{C}\right)\end{array}$} & \multirow{5}{*}{5 days } & \multirow{5}{*}{ Females } & $0 g^{*}$ & $30 \mathrm{G}$ & $30 \mathrm{H}$ & --- & --- \\
\hline & & & $1 g^{*}$ & $31 \mathrm{G}$ & $31 \mathrm{H}$ & --- & --- \\
\hline & & & $2 g^{*}$ & --- & --- & --- & --- \\
\hline & & & $1 g\left(14^{\circ} \mathrm{C}\right)$ & --- & --- & --- & --- \\
\hline & & & $\lg \left(24^{\circ} \mathrm{C}\right)$ & $3 o G$ & $3 \mathrm{oH}$ & 3oI & --- \\
\hline \multirow{6}{*}{$\begin{array}{l}\text { LDC (Large } \\
\text { Diameter Centrifuge) } \\
\left(72 \mathrm{~h} / 22^{\circ} \mathrm{C}^{2}\right)\end{array}$} & \multirow{4}{*}{5 days } & \multirow{4}{*}{ Females } & $2 g^{\#}$ & $\mathrm{H} 2 \mathrm{~V}$ & $\mathrm{H} 2 \mathrm{X}$ & $\mathrm{H} 2 \mathrm{Y}$ & $\mathrm{H} 2 \mathrm{Z}$ \\
\hline & & & $1 g^{\#}$ & H0Q & H0R & --- & --- \\
\hline & & & $1 g$ & H1Q & H1R & --- & --- \\
\hline & & & $2 g^{\#}$ & L2V & $\mathrm{L} 2 \mathrm{X}$ & $\mathrm{L} 2 \mathrm{Y}$ & L2Z \\
\hline & \multirow[t]{2}{*}{20 days } & \multirow[t]{2}{*}{ Females } & $1 g^{\#}$ & L0Q & L0R & --- & --- \\
\hline & & & $1 g$ & L1Q & L1R & --- & --- \\
\hline
\end{tabular}

Main comparison experiment was performed in similar conditions in the three devices, while secondary experiments (shaded in grey in the table) has been done with different set ups in the three simulators.

1. Due to the technical constrains RPM experiments last 1 day longer than the others but final age was similar.

2. The hypergravity centrifuge (LDC in ESTEC) was still on the trial period of operation when this experiment was done so a higher mandatory temperature was used in days-long experiments. ${ }^{\star}$ means the presence of a

high magnetic field. \# means the presence of mechanical/rotational disturbances.

across conditions, so it is considered as a unit (centroid). The different colours correspond to the average gene expression intensity of a centroid for each environment; in our case, the average log2 ratio of the genes contained in the cluster/ centroid in each environment compared to $1 \mathrm{~g}$ controls. The GEDI program locates similar centroids close to each other in the mosaic, creating an image of the transcriptome and facilitating its analysis as an entity by simple visualization and through different conditions. The GEDI analysis clustered 18952 probe-sets which were placed in $20 \times 16$ mosaics with an average of 59 genes per centroid, as in Figure 1.

At first sight, the transcriptome shows a subtle and variable response to altered gravity. By focusing on the log2 expression change ratio scale in the bottom right-hand corner of Figure 1, we note that the changes in expression which can be differentiated have a signal ratio of up to 1.40 for the increased probe sets and 0.73 for the decreased probe sets. This indicates that the observed changes in the figures would not usually be detectable with a classical approach in which changes between a ratio of 2 and 0.5 are treated as random noise and are neglected. Using a clustering analysis, even small individual gene expression variations are coherent within each cluster and thus, remain statistically meaningful. Globally, these results imply that repressed and over-expressed genes are not balanced in these experiments. This is indicated in the middle point of the graph scale (1.06 ratio), which shows that there are more clusters of over- expressed genes than clusters of repressed genes. Also, a subtle over-expression of the overall transcriptome (green general background) is produced by exposure to altered gravity, as revealed in Figure $\mathbf{1} \mathbf{A}$, especially for exposure at $22^{\circ} \mathrm{C}$ in the large diameter centrifuge. Note, however, that the opposite effect is produced in the RPM microgravity simulator (blue general background).

The effect of mechanical simulators on gene expression depends upon the gender and age of the Drosophila population

The two simulated microgravity panels in the first column of Figure $1 \mathrm{~A}$ correspond to exposure in the RPM of females (upper row) and males (lower row). Note the differences between the two genders in over-expression (red areas) and that, for one gender, the over-expressed areas correspond to downregulated areas for the other gender. This opposite effect for males and females, which has been observed previously in our complementary experiments [18], can also be seen in lessexpressed areas of the image. This suggests a global effect in 


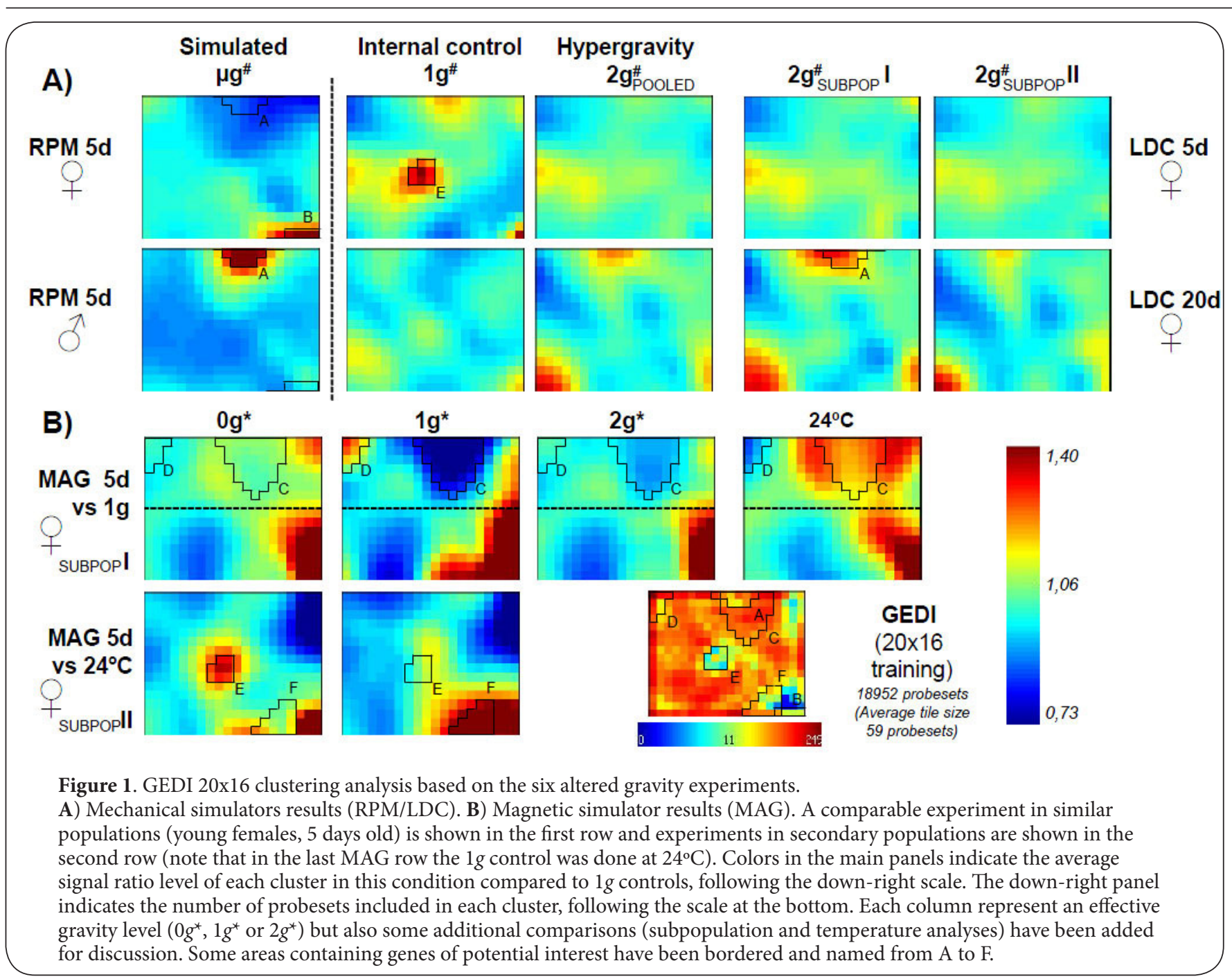

the Drosophila transcriptome. The major areas of change in Figure $1 \mathrm{~A}$ are marked with an $\mathrm{A}$ for over-expression of males in the RPM and a $B$ for females.

The remainder of Figure $1 \mathrm{~A}$ shows the results obtained using the centrifuge. We use $g^{\#}$ to refer to the modified gravity induced by the centrifuge or by mechanical rotation, rather than magnetic levitation. The internal control column corresponds to $1 g^{\#}$ where the sample is placed in the central axis of the centrifuge; the hypergravity column corresponds to $2 g^{\#}$ (pooled analysis with four $2 g^{\#}$ arrays versus three $1 g$ arrays) and the last two columns are separate analyses of the $2 g^{\#}$ samples to check reproducibility (2vs3 and 2vs3 arrays). As can be seen from the first row of Figure $1 \mathrm{~A}$, we see very little effect of the modified gravity apart from the extended green background when young females are exposed to $2 g^{*}$; both subanalyses are similar. In the second row of Figure $1 \mathbf{A}$, there is a small but observable effect when we expose mature females to modified gravity, suggesting a higher sensitivity of the mature females to centrifugation. The subanalysis exhibits some variations; the red area of over-expression in the first row of images is noticeable in subpopulation I but hardly visible in subpopulation II. Nevertheless, the overall pattern is similar, suggesting that variations within individuals are not an important issue using our methodology.

In high magnetic field experiments, the effect of the magnetic field dominates the gene expression of Drosophila

We performed experiments in the bore of our magnetic levitation cryostat to compare the changes in gene expression with those obtained in the random positioning machine and the large diameter centrifuge. In the magnetic field experiments, young females were exposed to altered gravity and high magnetic field conditions in the bore of the magnet for 3 days at $14^{\circ} \mathrm{C}$. The flies were contained in three tubes, one enclosing the $0 g^{*}$ stable levitation point of water, one enclosing the $1 g^{*}$ point and one enclosing the $2 g^{*}$ point. The results are shown in Figure 1B. As expected, the transcriptome 
Herranz et al. Genomics Discovery 2013,

http://www.hoajonline.com/journals/pdf/2052-7993-1-1.pdf

Table 2. Top ten GO Biological processes in the probesets included in selected areas of interest (A to F).

\begin{tabular}{|c|c|c|c|c|c|c|c|c|c|}
\hline $\begin{array}{l}\text { A area (RPM } \\
\text { increased in males) }\end{array}$ & $p$-Value & $\begin{array}{l}\text { B area (RPM } \\
\text { increased in } \\
\text { females) }\end{array}$ & $p$-Value & $\begin{array}{l}\mathrm{C} \text { area (Overall } \\
\text { magnet repressed) }\end{array}$ & $p$-Value & $\begin{array}{l}D \text { area (Overall } \\
\text { magnet over } \\
\text { expressed) }\end{array}$ & $p$-Value & $\begin{array}{l}\mathrm{F} \text { area }\left(1 g^{*}\right. \\
\text { position only } \\
\text { over expressed) }\end{array}$ & $p$-Value \\
\hline $\begin{array}{l}\text { GO:7049: } \\
\text { cell cycle }\end{array}$ & $7,44 \mathrm{E}-23$ & $\begin{array}{l}\text { GO: } 45297: \\
\text { post-mating } \\
\text { behavior }\end{array}$ & $2,31 \mathrm{E}-21$ & $\begin{array}{l}\text { GO:6139: nucleobase, } \\
\text { nucleoside, nucleotide } \\
\text { and nucleic acid } \\
\text { metabolism }\end{array}$ & $4,05 \mathrm{E}-82$ & $\begin{array}{l}\text { GO:6091: generation } \\
\text { of precursor } \\
\text { metabolites and } \\
\text { energy }\end{array}$ & $4,55 \mathrm{E}-24$ & $\begin{array}{l}\text { GO: } 45861: \\
\text { negative } \\
\text { regulation of } \\
\text { proteolysis }\end{array}$ & $8,30 \mathrm{E}-05$ \\
\hline $\begin{array}{l}\text { GO: } 279: \\
\text { M phase }\end{array}$ & $7,67 \mathrm{E}-23$ & $\begin{array}{l}\text { GO:7617: mating } \\
\text { behavior }\end{array}$ & $1,27 \mathrm{E}-13$ & $\begin{array}{l}\text { GO: } 43283: \\
\text { biopolymer } \\
\text { metabolism }\end{array}$ & $9,92 \mathrm{E}-69$ & $\begin{array}{l}\text { GO:6118: electron } \\
\text { transport }\end{array}$ & $3,74 \mathrm{E}-20$ & $\begin{array}{l}\text { GO:7617: } \\
\text { mating behavior }\end{array}$ & 0,000437 \\
\hline $\begin{array}{l}\text { GO:6259: DNA } \\
\text { metabolism }\end{array}$ & $1,90 \mathrm{E}-21$ & $\begin{array}{l}\text { GO:19098: } \\
\text { reproductive } \\
\text { behavior }\end{array}$ & $2,06 \mathrm{E}-13$ & $\begin{array}{l}\text { GO:6259: DNA me- } \\
\text { tabolism }\end{array}$ & $3,55 \mathrm{E}-58$ & $\begin{array}{l}\text { GO:42773: ATP } \\
\text { synthesis coupled } \\
\text { electron transport }\end{array}$ & $8,98 \mathrm{E}-18$ & $\begin{array}{l}\text { GO:19098: } \\
\text { reproductive } \\
\text { behavior }\end{array}$ & 0,000582 \\
\hline $\begin{array}{l}\text { GO:6260: DNA } \\
\text { replication }\end{array}$ & $5,22 \mathrm{E}-21$ & $\begin{array}{l}\text { GO:18991: } \\
\text { oviposition }\end{array}$ & $4,69 \mathrm{E}-11$ & $\begin{array}{l}\text { GO:50794: regulation } \\
\text { of cellular process }\end{array}$ & $1,15 \mathrm{E}-46$ & $\begin{array}{l}\text { GO:6119: oxidative } \\
\text { phosphorylation }\end{array}$ & $4,30 \mathrm{E}-15$ & $\begin{array}{l}\text { GO:51248: } \\
\text { repression } \\
\text { of protein } \\
\text { metabolism }\end{array}$ & 0,000689 \\
\hline $\begin{array}{l}\text { GO:7067: } \\
\text { mitosis }\end{array}$ & $1,12 \mathrm{E}-20$ & $\begin{array}{l}\text { GO: } 45434 \text { GO: } 7621: \\
\text { female receptivity } \\
\text { negative regulation, } \\
\text { pre \& post-mating }\end{array}$ & $5,05 \mathrm{E}-09$ & $\begin{array}{l}\text { GO:51244: regulation } \\
\text { of cellular physiological } \\
\text { process }\end{array}$ & $2,08 \mathrm{E}-46$ & $\begin{array}{l}\text { GO:51606: } \\
\text { detection of stimulus }\end{array}$ & $6,53 \mathrm{E}-14$ & $\begin{array}{l}\text { GO: } 8063: \\
\text { Toll signaling } \\
\text { pathway }\end{array}$ & 0,000792 \\
\hline $\begin{array}{l}\text { GO:19953: } \\
\text { sexual } \\
\text { reproduction }\end{array}$ & $1,21 \mathrm{E}-18$ & $\begin{array}{l}\text { GO: } 50795: \\
\text { regulation of } \\
\text { behavior }\end{array}$ & $1,55 \mathrm{E}-08$ & $\begin{array}{l}\text { GO:50791: regulation } \\
\text { of physiological process }\end{array}$ & $2,46 \mathrm{E}-44$ & $\begin{array}{l}\text { GO:9581: detection } \\
\text { of external stimulus }\end{array}$ & $1,23 \mathrm{E}-13$ & $\begin{array}{l}\text { GO:7614: short- } \\
\text { term memory }\end{array}$ & 0,000885 \\
\hline $\begin{array}{l}\text { GO: } 7292: \\
\text { female gamete } \\
\text { generation }\end{array}$ & $6,20 \mathrm{E}-17$ & $\begin{array}{l}\text { GO: } 46008 \text { : } \\
\text { regulation of female } \\
\text { receptivity, post- } \\
\text { mating }\end{array}$ & $3,50 \mathrm{E}-08$ & $\begin{array}{l}\text { GO:50789: regulation } \\
\text { of biological process }\end{array}$ & $2,68 \mathrm{E}-41$ & $\begin{array}{l}\text { GO:6120: } \\
\text { mitochondrial } \\
\text { electron transport, } \\
\text { NADH to } \\
\text { ubiquinone }\end{array}$ & $3,71 \mathrm{E}-13$ & $\begin{array}{l}\text { GO:6118: } \\
\text { electron } \\
\text { transport }\end{array}$ & 0,000949 \\
\hline $\begin{array}{l}\text { GO:9993: } \\
\text { oogenesis } \\
\text { (sensu Insecta) }\end{array}$ & $1,22 \mathrm{E}-16$ & $\begin{array}{l}\text { GO: } 7320: \\
\text { insemination }\end{array}$ & $2,07 \mathrm{E}-07$ & GO:7049: cell cycle & $9,07 \mathrm{E}-39$ & $\begin{array}{l}\text { GO:7602: } \\
\text { phototransduction }\end{array}$ & $6,52 \mathrm{E}-13$ & --- & --- \\
\hline $\begin{array}{l}\text { GO:3: } \\
\text { reproduction }\end{array}$ & $1,78 \mathrm{E}-16$ & $\begin{array}{l}\text { GO: } 45924 \text { : regulation } \\
\text { of female receptivity }\end{array}$ & $2,07 \mathrm{E}-07$ & GO:6350: transcription & $2,60 \mathrm{E}-35$ & $\begin{array}{l}\text { GO:9582: } \\
\text { detection of abiotic } \\
\text { stimulus }\end{array}$ & $9,23 \mathrm{E}-13$ & --- & --- \\
\hline $\begin{array}{l}\text { GO: } 7276: \\
\text { gametogenesis }\end{array}$ & $6,71 \mathrm{E}-16$ & $\begin{array}{l}\text { GO:50876: } \\
\text { reproductive } \\
\text { physiological process }\end{array}$ & $2,07 \mathrm{E}-07$ & GO:279: M phase & $5,63 \mathrm{E}-34$ & $\begin{array}{l}\text { GO: } 9583 \text { : } \\
\text { detection of light } \\
\text { stimulus }\end{array}$ & $3,15 \mathrm{E}-12$ & --- & --- \\
\hline
\end{tabular}

Overlapping GO groups has been omitted. E area does not offer any statistically meaning result using Gene Spring based GO analysis.

responds more strongly when this suboptimal temperature is used in combination with the magnetic field. There is a clear difference between the lower half of the images (indicated by a dash line within Figure 1B first row panels, very similar for the four images including also the comparison with a $24^{\circ} \mathrm{C}$ control to detect the temperature effect) and the clusters located above the dashed line, (in which is possible to locate parts $C$ and $D$ as areas of the transcriptome that appear to behave oppositely at the $0 g^{*}$ and $2 g^{*}$ positions). A similar but more pronounced effect of magnetic field is observed in flies from the tube in the $1 g^{*}$ position compared to the $0 g^{*}$ or $2 g^{*}$ positions. This could be because the magnetic field intensity is stronger $(\mathrm{B}=16 \mathrm{~T})$ in the $1 g^{*}$ position than for the $0 g^{*}$ or $2 g^{*}(12 \mathrm{~T})$.

For the experiment on Subpopulation II (last row Figure 1B), it is also interesting to note that although the gene expression of flies in the $0 g^{*}$ and $1 g^{*}$ positions share a similar pattern due to the temperature effect, there are also over-expression and repression areas in the $0 g^{*}$ position which also appear in the $1 g^{\#}, 5$ day-exposure rotational control using the LDC, as shown in the $E$ boxes in Figure 1. An interesting over-expressed area (area $\mathrm{F}$ in Figure 1) consistently appears in both magnet experiments in the $1 g^{*}$ position but not in the $0 g^{*}$ position.

Gene ontology analysis reveals a relation between behavioral patterns in altered gravity conditions and gene expression profile

To determine the groups of genes that are more related in their response to altered gravity, we performed a Gene Ontology (GO) analysis based on the gene lists extracted from the areas selected in Figure 1. Table 2 summarises these results. A full list of GO groups with a raw $p$-value $<0.001$ is presented as Supplementary Material. Two biological processes are detected in area A (genes over-expressed in RPM females), namely mitosis/cell division and reproductive behaviour (Table 2). Only the second element, mating-related genes, is also detected in area B. Area C (including area A) contains the mitosis/cell division GO groups together with enhanced transcriptional activity of the cells. Area D (over-expressed in the $1 g^{*}$ position of the magnet and in the temperature control) 
Herranz et al. Genomics Discovery 2013,

is related to energy metabolism and mitochondrial elements. Area $\mathrm{E}$ is small and contains an insufficient number of genes to produce $\mathrm{GO}$ enrichment results, but Area $\mathrm{F}$ (over-expressed just in both $1 g^{*}$ magnet controls) provides a relevant mixture of energy-related genes and mating/reproductive behaviour GO groups (Table 2).

\section{Discussion}

It is established that Drosophila imagoes exhibit a marked enhancement in motility when they are exposed to altered gravity conditions, due in part to their misorientation relative to the gravity vector $[18,22,23]$. Recent work has shown that differences in the age and gender of the imagoes can influence the degree of responsiveness to altered gravity, and suggested that altered motility can have a consequence by reducing mating/sexual behaviour and increasing energy metabolism and aging [24]. Microgravity conditions in spacecraft $[25,26]$ and hypergravity $[\mathbf{2 7}, \mathbf{2 8}]$ are also known to have a strong impact on the aging process of Drosophila.

Gene ontology enrichment analysis suggests that changes in mating behaviour and energy metabolism-dependent motility experienced by Drosophila in microgravity and hypergravity can also be detected at the molecular level in simulated modified gravity experiments. Interestingly, the internal controls used in the ground-based facility experiments described here also reveal some effects on the gene expression profile, possibly due to magnetic stresses in levitation or subtle mechanical forces in the RPM such as vibrations, other than those which compensate gravity. Nevertheless, these results, in combination with earlier experiments in real or simulated microgravity conditions $[7,29]$, indicate that the transcriptome is finely tuned to Earth's gravity and that the synergic effects exerted by microgravity and environmental suboptimal conditions may be explained by this "out of tune" state of the transcriptome in microgravity.

The original expectation of our analysis was that a common group of gravity-responding genes would be identified, as was the case for simpler unicellular systems [30]. However, the case of Drosophila is not as straightforward. Our data show that some genes respond dramatically to the different simulations but the effect seems to be more related to behavioural changes resulting from artefacts of the microgravity simulation technique, i.e. additional forces unique to the particular simulation technique, rather than from effects of microgravity and hypergravity on the cells.

Previous analyses of microgravity effects on gene expression have been limited by the usual constraints of experiments in spacecraft [31,32]. Limited amounts of oxygen, light and suboptimal temperature was even stronger in spaceflight microgravity samples. Some of the genes detected in those experiments and also in the experiments reported here appear to be related to a coordinated response of the organism under an undefined stress condition. Microgravity is a stimulus that biological organisms have never experienced during the millions of years of their biological evolution on Earth. It is possible that the observed energy-related components, heat shock proteins, external/abiotic stimuli sensors and assembly machinery are stimulated because the microgravity conditions indirectly affect the cell cycle and proliferation. In Drosophila, Hsp70 seems to be a mediator of the aging-protective effect induced by mild hypergravity [28], a relation also highlighted in mammals $[33,34]$. A preliminary genome scale analysis of spaceflight response in nematodes [6] has also detected stress links, though this is the first time that microgravity conditions have been linked to a genome-scale stress related response in Drosophila.

Future studies should extend the findings reported here. The availability of improved instrumentation on the ISS, especially now that the European Columbus and the Japanese Kibo modules have been launched and installed, will allow similar experiments to be performed in real microgravity conditions, but with fewer constraints than in previous spaceflight experiments. Until these facilities are available, ground-based microgravity simulation facilities continue to be useful. Future experiments, which employ a wider range of gravity levels than those used here, will identify the low and high gravity thresholds for these overall genome effects and confirm whether a key set of gravity-affected genes and also the phenotypic consequences of their modified expression can be identified. This approach will optimise the use of ground-based facilities for informing the design of the much more expensive experiments in space.

\section{Competing interests}

The authors declare that they have no competing interests.

\section{Authors' contributions}

$\mathrm{RH}$ conceived of the study, carried out the flies handling on-site, RNA extraction and microarray analyses including bioinformatics processing of the expression data and drafted the manuscript. CED and RJAH participated in the magnetic levitation instrument calibration and adaptation. JvL participated in the RPM and LDC instrument calibration and adaptation. RJAH, LE, JVL and FJM participated in the study design and coordination and helped to draft the manuscript. All authors read and approved the final manuscript.

\section{Acknowledgment}

We dedicate this paper to the memory of our colleague and friend Professor Roberto Marco who passed away in 2008, and whose mentorship and inspiration was crucial to this research. This work was supported by grants from the Spanish Space Program in the "Plan Nacional de Investigacion Cientifica y Desarrollo Tecnologico" [ESP2006-13600-C02-01] and MICINN [AYA2009-07792-E]; the Dutch NWO-ALW-SRON grant [MG-057] and the UK Engineering and Physical Sciences Research Council, Basic Technology grant [GR/S83005/01] and Basic Technology Translation grant [EP/G037647/1]. R.J.A.H acknowledges EPSRC for support under a Research Fellowship; grant nos. EP/I004599/1 and EP/J005452/1. R. Herranz was supported by Spanish Ministerio de Educacion y Ciencia International Research Centers fellowships program in ESTEC and by the Consejo Superior de Investigaciones Cientificas CSIC JAE- 
Herranz et al. Genomics Discovery 2013,

Doc contract. We also thank Aida Villa (IIB-UAM, Madrid, Spain), Allan Dowson, Lobke Zuijderduijn, Jutta Krause and Peter Schiller (ESTEC-ESA, Noordwijk, The Netherlands) and Michael Davey, Oliver Larkin and Paul Anthony (Nottingham University, UK) for discussions and excellent technical assistance during our visit to the ground based facilities.

\section{Publication history}

Received: 11-Feb-13 Revised: 17-Apr-13

Accepted: 14-May-2013 Published: 20-May-2013

\section{References}

1. Brinckmann E: Biology in Space and Life on Earth. Weinheim, Germany: Wiley 2007. I Book

2. Clément G, Slenzka K: Fundamentals of Space Biology: Research on Cells, Animals, and Plants in Space. New York: Springer 2006. I Book

3. Häder DP, Hemmersbach R, Lebert M: Gravity and the Behavior of Unicellular Organisms. New York: Cambridge University Press; 2005. I Book

4. Marthy HJ: Developmental biology research in Space. Amsterdam: Elsevier; 2003. I Book

5. Moore D, Bier P, Oser H: Biological and medical research in space: an overview of life sciences research in microgravity. Berlin: SpringerVerlag; 1996. | Book

6. Selch F, Higashibata A, Imamizo-Sato M, Higashitani A, Ishioka N, Szewczyk NJ and Conley CA: Genomic response of the nematode Caenorhabditis elegans to spaceflight. Adv Space Res 2008, 41:807-815. | PubMed Abstract | PubMed Full Text

7. Herranz R, Benguria A, Lavan DA, Lopez-Vidriero I, Gasset G, Javier Medina F, van Loon JJ and Marco R: Spaceflight-related suboptimal conditions can accentuate the altered gravity response of Drosophila transcriptome. Mol Ecol 2010, 19(19):4255-4264. I Article I PubMed

8. Borst AG, van Loon JJWA: Technology and Developments for the Random Positioning Machine, RPM. Microgravity Sci Technol 2009, 21(4):287-292. | Article

9. Hoson T, Kamisaka S, Masuda Y, Yamashita M: Changes in plant growth processes under microgravity conditions simulated by a threedimensional clinostat. Bot Mag 1992, 105:53-70. I Article

10. Regnard J, Heer M, Drummer C and Norsk P: Validity of microgravity simulation models on earth. Am J Kidney Dis 2001, 38:668-74. I Article I PubMed

11. van Loon JJ, Folgering EH, Bouten CV and Smit TH: Centrifuges and inertial shear forces. J Gravit Physiol 2004, 11:29-38. I PubMed

12. van Loon JJ, Folgering EH, Bouten CV, Veldhuijzen JP and Smit TH: Inertial shear forces and the use of centrifuges in gravity research. What is the proper control? J Biomech Eng 2003, 125:342-6. | Article | PubMed

13. van Loon JJWA: Some history and use of the Random Positioning Machine, RPM, in gravity related research. Adv Space Res 2007, 39:1161-1165. | Article

14. Beaugnon E, Tournier R: Levitation of organic materials. Nature 1991, 349:470. | Article

15. Beaugnon $\mathrm{E}$, Tournier R: Levitation of water and organic substances in high static magnetic fields. J Phys III France 1991, 1:1423-1428. | Article

16. Berry MV, Geim AK: Of flying frogs and levitrons. Eur J Phys 1997, 18:307-313. | Article

17. Dijkstra CE, Larkin OJ, Anthony P, Davey MR, Eaves L, Rees CE and Hill RJ: Diamagnetic levitation enhances growth of liquid bacterial cultures by increasing oxygen availability. J R Soc Interface 2011, 8:334-44. | Article | PubMed Abstract | PubMed Full Text

18. Hill RJ, Larkin OJ, Dijkstra CE, Manzano Al, de Juan E, Davey MR, Anthony P, Eaves L, Medina FJ, Marco R and Herranz R: Effect of magnetically simulated zero-gravity and enhanced gravity on the walk of the common fruitfly. J R Soc Interface 2012, 9:1438-49. | Article I PubMed Abstract | PubMed Full Text

19. Valles JM, Jr. and Guevorkian K: Low gravity on earth by magnetic levitation of biological material. J Gravit Physiol 2002, 9:P11-4. | Article I PubMed

20. Valles JM, Jr., Lin K, Denegre JM and Mowry KL: Stable magnetic field gradient levitation of Xenopus laevis: toward low-gravity simulation. Biophys J 1997, 73:1130-3. | Article | PubMed Abstract | PubMed Full
Text

21. Eichler GS, Huang S and Ingber DE: Gene Expression Dynamics Inspector (GEDI): for integrative analysis of expression profiles. Bioinformatics 2003, 19:2321-2. | Article I PubMed

22. Benguria A, Grande E, de Juan E, Ugalde C, Miquel J, Garesse R and Marco R: Microgravity effects on Drosophila melanogaster behavior and aging. Implications of the IML-2 experiment. J Biotechnol 1996, 47:191-201. | Article | PubMed

23. de Juan E, Benguría A, Villa A, Leandro LJ, Herranz R, Duque P, Horn E, Medina FJ, Loon JV, Marco R: The "AGEING" Experiment in the Spanish Soyuz Mission to the International Space Station. Microgravity Sci Technol 2007, 19(3-4):170-174. | Article

24. Serrano P, van Loon JJWA, Medina FJ, Herranz R: Relation between motility, accelerated aging and gene expression in selected drosophila strains under altered gravity conditions. Microgravity Sci Technol 2013 25(1 (Effects of Altered Gravity in Life and Physical Sciences - Part 2)). Article

25. Marco R, Vernos I, Gonzalez J and Calleja M: Embryogenesis and aging of Drosophila melanogaster flown in the space shuttle. Preliminary analysis of experiment fly 15E. Naturwissenschaften 1986, 73:431-2. | Article I PubMed

26. Vernos I, Gonzalez-Jurado J, Calleja M and Marco R: Microgravity effects on the oogenesis and development of embryos of Drosophila melanogaster laid in the Spaceshuttle during the Biorack experiment (ESA). Int J Dev Biol 1989, 33:213-26. | Article I PubMed

27. Le Bourg $\mathrm{E}$ : A review of the effects of microgravity and of hypergravity on aging and longevity. Exp Gerontol 1999, 34:319-36. | Article | PubMed

28. Le Bourg E, Valenti P and Payre F: Lack of hypergravity-associated longevity extension in Drosophila melanogaster flies overexpressing hsp70. Biogerontology 2002, 3:355-64. | Article | PubMed

29. Herranz R, Larkin OJ, Dijkstra CE, Hill RJ, Anthony P, Davey MR, Eaves L, van Loon JJ, Medina FJ and Marco R: Microgravity simulation by diamagnetic levitation: effects of a strong gradient magnetic field on the transcriptional profile of Drosophila melanogaster. BMC Genomics 2012, 13:52. I Article | PubMed Abstract | PubMed Full Text

30. Wilson JW, Ramamurthy R, Porwollik S, McClelland M, Hammond T, Allen $\mathrm{P}, \mathrm{Ott} \mathrm{CM}$, Pierson DL and Nickerson CA: Microarray analysis identifies Salmonella genes belonging to the low-shear modeled microgravity regulon. Proc Natl Acad Sci U S A 2002, 99:13807-12. | Article I PubMed Abstract I PubMed Full Text

31. Herranz R, Laván D, Benguría A, Duque P, Leandro L, Gasset G, Zaballos A, Medina FJ, Loon JJv, Marco R: The "Gene" Experiment in the Spanish Soyuz Mission to the International Space Station. Effects of cold transportation. Microgravity Sci Technol 2007, 19 (3-4):196-200. | Article

32. Herranz R, Laván DA, Medina FJ, van Loon JJ, Marco R: The "Gene" Experiment in the Spanish Soyuz Mission to the International Space Station. II. Effects of oxygen concentration constrain. Microgravity Sci Technol 2009, 21(4):299-304. | Article

33. Nichols $\mathrm{HL}$, Zhang $\mathrm{N}$ and Wen $\mathrm{X}$ : Proteomics and genomics of microgravity. Physiol Genomics 2006, 26:163-71. I Article I PubMed

34. van Loon JJWA, Tanck E, van Nieuwenhoven FA, Snoeckx LHEH, de Jong HAA, Wubbels RJ: A brief overview of animal hypergravity studies. J Gravit Phys 2005, 12(1):5-10.

Citation:

Herranz R, Hill R J, Dijkstra C E, Eaves L, van Loon J J and Medina F J: The behavioural-driven response of the Drosophila imago transcriptome to different types of modified gravity. Genomics Discovery 2013, 1:1. http://dx.doi.org/10.7243/2052-7993-1-1 